\title{
Lexis
}

Journal in English Lexicology

$11 \mid 2018$

Lexis in Languages for Specific Purposes (LSP)

\section{Lexicogenic matrices and institutional roles of U.S. military jargon}

Anthony Saber

\section{OpenEdition}

Journals

\section{Electronic version}

URL: http://journals.openedition.org/lexis/1179

DOI: $10.4000 /$ lexis. 1179

ISSN: 1951-6215

\section{Publisher}

Université Jean Moulin - Lyon 3

\section{Electronic reference}

Anthony Saber, «Lexicogenic matrices and institutional roles of U.S. military jargon », Lexis [Online],

11 | 2018, Online since 30 April 2018, connection on 01 May 2019. URL : http://

journals.openedition.org/lexis/1179; DOI : 10.4000/lexis.1179

This text was automatically generated on 1 May 2019.

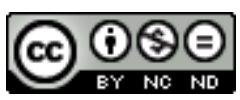

Lexis is licensed under a Creative Commons Attribution-NonCommercial-NoDerivatives 4.0 International License. 


\section{Lexicogenic matrices and institutional roles of U.S. military jargon}

Anthony Saber

\section{Introduction : the four types of military lexis}

1 Although some military expressions (e.g. "collateral damage ${ }^{1}$," "Roger that ${ }^{2}$," "to go $\mathrm{AWOL}^{3}$," "FUBAR") have become part of everyday informal language, the terminology used in the U.S. military is of a highly technical nature, and generally cannot be understood by outsiders without advanced knowledge of military matters ${ }^{5}$. To decipher an abbreviation such as "C4S," for example, one should look up its definition in the DOD Dictionary of Military and Associated Terms ${ }^{6}$ [2017: 271], which explains that it stands for "command, control, communications, and computer systems," a tactical concept describing the integration of digital resources into the management of the battlefield. The DoD Dictionary indexes the terminology officially approved by the U.S. military ${ }^{7}$ to refer to tactical concepts, materiel, military facilities, actions and forces. Following Paveau [1994], we designate this official terminology, which we consider as the first type of military lexis, as a "technolect."

In addition to this official, standardized terminology, military personnel may need to use other types of lexis: frontline units routinely resort to "brevity codes"s "judy," for instance, means that the "aircrew has radar or visual contact on the correct target, has taken control of the intercept and only requires situation awareness information; Controller will minimize radio transmissions"9) and procedure words or "prowords"10 (e.g. "wilco" means "will comply with received instructions" ${ }^{11}$ ) which enable them to exchange tactical information in an economical, swift, efficient and unambiguous fashion, in training or combat situations. We designate this second type of military lexis as " tactical codes" (which may include NATO codes not listed in the DoD Dictionary). 
3 A third type of military lexis can be designated as "highly technical nomenclatures," i.e. technical designations for military equipment or weaponry. An example of this type of lexis is the GBU-28 (GBU stands for "guided bomb unit" - interestingly, this designation is not listed in the DoD Dictionary), a laser-guided bomb specifically designed by the U.S. Air Force, Texas Instruments and Raytheon ${ }^{12}$ to penetrate bunkers or hardened enemy facilities (it is often nicknamed the "bunker-busting bomb").

4 In this study, however, we focus on a fourth type of military lexis, i.e. military jargon. We define military jargon as a lexis (1) spontaneously created by the members of military units (as opposed to the official technolect, which is created, sponsored and approved by senior authorities in the military), (2) used in non-official, off-duty informal contexts, (3) transmitted and spread through oral tradition within military units, and (4) generally mobilized in ordinary everyday conversations ${ }^{13}$.

5 To the best of our knowledge, only a few previous studies (Riordan [1947], Howard [1956], Clark [1990], Reinberg [1991], Chaloupsky [2005], Bay [2007], Rottman [2009], Axelrod [2013], Dalzell [2014], Dickson [2014]) have investigated U.S. military jargon, and most of them adopted a strictly lexicographical perspective. Some studies in American culture have also envisaged U.S. military jargon from the viewpoint of folklore or collective identity (Cornell [1981], Gillespie [2012], Romanov [2014]). In this study, however, we adopt a different perspective. Our aim is twofold: first, to characterize the mechanisms at work in the genesis of military jargon; second, to identify the institutional roles played by jargon within the U.S. military.

\section{Selection of lexical items}

6 By its very nature as an informal lexis, military jargon is not (in general) officially sanctioned by the military institution: hence, no "official" dictionaries or glossaries of jargon were available from which to select lexical items for our research. To collect samples of U.S. military jargon, we thus used several alternative sources, which appeared as reliable (a list of our sources is available in appendix 1). We could have conducted an extensive review of the countless websites curated by military units ${ }^{14}$ and harboring glossaries of jargon, but this endeavor was beyond the scope of this study, and preliminary investigations indicated a significant degree of overlap between these sources and the sources cited above. Additionally, we used some items from glossaries established by Axelrod [2013], Bay [2007] and Dickson [2014]. The resulting dataset of 190 items mostly includes relatively recent jargon (from the post-Vietnam era), but we occasionally included less recent terms and expressions. We were able to cross-reference a significant proportion of lexical items from at least two or three different sources, thus increasing the reliability and representativeness of our lexical database.

\section{Lexicogenic matrices of U.S. military jargon}

\subsection{Spontaneous neology in U.S. military units}

7 Jargon is abundantly used in the U.S. military. In contrast with the technolect, it is not proposed, regulated nor standardized by senior military authorities, but spontaneously created by military personnel for informal interactions. Lexicogenic mechanisms at work 
in U.S. military jargon may be highly inventive and unexpected, as explained by Miller [1998: 166] in the context of the U.S. Marine Corps:

"Zeros" was a slang ${ }^{15}$ term for officers that was derived from the pay scales promulgated by the military. Officers were identified by $0-1,0-2$, etc., while enlisted men, sometimes referred to as Es, were identified by E-1, E-2, etc.

8 As can be seen in this example, the final neologism results from a complex mechanism involving a metonymic selection of the number " 0 " as an official administrative designation associated with officer status, a desire to create a hilarious term designating officers, combined with the will to express the frustration of enlisted personnel with the (perceived) lack of competence of higher-ranking senior personnel. In other words, the neology mechanisms at work in this specific example are not primarily driven by the referential function of slang identified by Calvet [1999: 49], who posited that the need to designate multiple objects and actions among the various trades and professions was the key driver of the abundance of slang: "Carpenters, farmers, fishermen, etc., have a [...] vocabulary, simply because they need to designate with accuracy objects or actions that non-specialists would not distinguish ${ }^{16}$." Calvet, as an example, cites the various names of the plane for cabinetmakers ("bouvet," "doucine," "fuilleret").

New military jargon may appear whenever U.S. troops participate in a conflict or are deployed abroad, and may remain part of their lexical capital over a long time in later years: expressions such as "The Blue" and "The Gray," which were used during the American Civil War (Dickson [2014]) to refer to the warring parties, have of course been forgotten, but the phrase "to see the elephant" (to see combat, action), which was also introduced during this conflict, is still used in the U.S. military.

\subsection{Definitions of lexicogenic matrices}

10 A first objective of this study was to identify the lexicogenic matrices of U.S. military jargon. As is well known, Tournier [1985] defined 15 lexicogenic matrices of neologisms (12 "internal matrices" - prefixation, suffixation, inverse derivation, juxtaposition, amalgam, onomatopoeia and ideophonic elements, conversion, metaphor, metonymy, aphaeresis, apocope, acronyms - and three "external" matrices based on lexical material from another language - morpho-semantic loans, semantic loans, morphological loans). To describe the specific lexicogenic mechanisms of jargon, Antoine [2004, 2008] proposed two additional matrices (deformation and puns). Sablayrolles [2006, 2012] proposed a new table of lexicogenic matrices partly based on Tournier's work, but including several new matrices such as synapsies, quasimorphems, or combinatory innovations.

11 A key distinction introduced by Tournier differentiates "internal" matrices from "external" ones (i.e. words borrowed from other languages). While this "external" matrix is highly productive in French slang, for example (bistro is derived from Russian, flouze, i.e. "money," from Arabic), we found only a few borrowings from other languages in our dataset: an example is "gedunk," which, according to the online dictionary maintained by the Naval History and Heritage Command ${ }^{17}$, "refers to ice cream, candy, potato chips, and other snack foods, as well as to the place on a ship where these items are sold," and appears to "derive from a Chinese word referring to a place of idleness, or a German word meaning to dunk bread in gravy or coffee." Occasionally, when deployed in foreign territories, U.S. forces can of course pick up a few local words and include them into their jargon: "hajji," for example, a derogatory term widely used during the second Gulf War to 
designate Iraqis, refers to the hajj, i.e. the sacred pilgrimage to Mecca that every Muslim should accomplish. More recent jargon includes "Johnny Jihad," i.e. a radical Islamist terrorist. However, Tournier's "external" lexicogenic matrix did not appear to support a significant amount of U.S. military jargon.

Drawing on this previous work by Tournier, Antoine and Sablayrolles, but noting that their respective models did not allow to accurately describe all the lexicogenic mechanisms matrices in our dataset, we attempted to rebuild a comprehensive list of lexicogenic matrices by adopting a bottom-up approach: after performing a manual analysis of all the items in our dataset, we inferred a new taxonomy of five main categories (semantic, morphological, phonological, collocational, and phrase-level lexicogenic matrices), which fall into several sub-categories (the full taxonomy is presented in appendix 2).

In the next section, we adopt the same order as in appendix 2 to present the different lexicogenic mechanisms governing U.S. military jargon.

\section{Semantic matrices of military jargon}

\subsection{Semanticization: semanticizing the military alphabet}

13 A common lexical practice in the military appears to consist in semanticizing groups of letters belonging to the military alphabet (as in Alpha, Charlie, Delta, Echo etc.). "Alpha Charlie," for example, stands for "ass chewing" (by a senior officer), "Charlie Fox-Trot" for "clusterfuck," "Tango Uniform" for "Tits Up" (i.e. deceased), "Whiskey Tango FoxTrot" for "What the fuck, over ${ }^{18}$," and "Oscar Mike ${ }^{19}$ " for "on the move". Of note is the "Blue Falcon" (a "Buddy Fucker," i.e. a traitor), which is formed through the same lexical template, although the official designation of " $\mathrm{F}$ " in the military alphabet is "Fox-Trot ${ }^{20}$." We termed this lexical matrix "semanticization," as it endows linguistic signs such as letters of the military alphabet with a specific meaning.

\subsection{Resemanticization}

\subsubsection{Resemanticized nouns}

Resemanticization appears to be used to create a common lexical code (which may contribute to building rapport and esprit de corps) among a closed military community. It seems to be associated with a somewhat cryptographic function, as in "The Crotch" (a resemanticized noun used by Marines to designate the U.S. Marine Corps during the Vietnam war). Marines also refer to Okinawa, which houses a large Marine Corps base, as "the Rock." In the U.S. Air Force, a "pig" is an aircraft plagued by frequent maintenance issues, the "Bone" designates the B-1 strategic bomber, and "the Hill" refers to the Air Force Academy in Colorado Springs. In the U.S. Marine Corps, a "mustang" is any officer who was promoted from the enlisted ranks. It should be noted that, although some resemanticized nouns seem to be widespread (e.g. "klicks," which refers to kilometers), the meaning of some of them may differ in each service: while a U.S. Navy "grape" is a technician tasked with refueling naval aircraft, the term "grape" refers to an easy assignment in the U.S. Air Force. 


\subsubsection{Resemanticized official abbreviations} routinely used in the U.S. military (thousands of them are listed in the DoD Dictionary). Therefore, military personnel tend to playfully resemanticize some of the abbreviations normally used in a formal, official context. Implicit criticism of military institutions is often part of this resemanticization process: NATO, for example, stands for "No action talk only," or "Nothing after two o'clock." In the U.S. Navy, official abbreviations describing types of vessels are similarly resemanticized to make fun of the constraints associated with life at sea: LHD (an abbreviation that usually designates a "Landing Helicopter Dock," i.e. a large amphibious vessel) becomes "Living Hell Daily," LST (Landing Ship Tank, another type of amphibious vessel) becomes a "Large Slow Target," SSN (a nuclear-powered attack submarine) which remains underwater for long periods of time, becomes "Saturdays, Sundays, and Night," while the prefix USS (as in USS Nimitz) becomes "Underway Saturday or Sunday." Among the U.S. Marines, Lance Corporals, officially designated as "LCPLs," are viewed as the "Last Cleaning Position Left" because they are often assigned cleaning duties.

\subsection{Metonymies}

Metonymies were defined by Bonhomme [1987] as changes in designation based on lexical items sharing a cotopia, i.e. a certain degree of semantic correlation. This mechanism is at work in elements of military jargon such as "Band-Aid" (a Viet-Nam war term for a corpsman), "pill pusher" (a U.S. Navy term for medical personnel), "Bullshit Bomb" (a device dropped from an aircraft and designed to disperse propaganda leaflets), "Dear John" (a spouse or a companion writing a letter to a service member to announce that she wishes to break up), "the Sandbox" (Iraq), or "snake eaters" (U.S. special forces, whose normal lifestyle consists in "roughing it" on the field).

\subsection{Metaphors}

Metaphor is one of the most productive lexical matrices in our dataset (53 items out of 190). Multiple (and competing) definitions of metaphors are available. Le Guern [1973: 43] explains that "metaphor appears as the synthetic formulation of all the semantic elements belonging to the usual significance of a word that are compatible with the new significance imposed by the context on the metaphoric use of this word." For Lakoff and Johnson [1980:5], metaphor is based on the superposition of two relative experiences, when we "understand and experience one kind of thing in terms of another." Charbonnel [1999:33] contends that "metaphorization can only occur when two heterogeneous realities are brought together." Bonhomme [1987] highlights the fact that, in contrast to metonymies in which two items share a certain degree of cotopia, metaphors are based on allotopia, i.e. on the fact that the two topic areas brought together by metaphorization are heterogeneous. For our analysis of metaphors in military jargon, and because it would be beyond the scope of this study to discuss available definitions of metaphors extensively, we shall adopt the following working definition: metaphor is a formulation that associates selected elements of meaning (or "semes") from two heterogeneous topic 
areas in a surprising fashion, thereby requiring interpretative work on the part of the addressee.

We can see these metaphorical mechanisms at work in expressions such as the "dome of obedience" (a military helmet): the dome-like shape of the helmet is selected from a first topic area related to military gear, whereas "obedience" is extracted from a second topic area, that of hierarchy in the military, in an implicit reference to the military nature of the helmet. The resulting formulation is humorous and surprising, and requires the addressee to rebuild the comparative mechanisms that led to the formulation of the metaphor. Similarly, the "fart sack" (a sleeping bag) refers, on the one hand, to a physiological phenomenon that occurs while sleeping, and on the other hand to the nature of the sleeping bag as a "container." As can be seen, only selected elements of meaning or "semes" are chosen from each of the two topic areas, as had been noted by Le Guern [1973: 15], who contended that metaphors relied on the "elimination, or more precisely the suspension of a proportion of the semes pertaining to the mobilized lexeme." As for metonymies in Bonhomme's theory [1987], the degree of semantic proximity or distance between the groups of semes originating from each topic area can be described in terms of cotopia and allotopia, respectively.

Antoine [2014] proposed a specific lexicogenic mechanism for metaphors in jargon, based on the principle of the "magnifying glass," (a single seme is strongly highlighted in the metaphor, to the detriment of other possible traits ${ }^{21}$ ). For example, in the saying "man is wolf to man," the seme of cruelty is selected as defining both man and wolf, and eclipses all other semes pertaining to the two topic areas. This appears to be a frequent process in military jargon, as in "fast mover" (a jet fighter), a metaphor which underlines the key characteristic of modern combat aircraft - their speed. The condensation of meaning into a tightly packed lexical formula contributes to its adoption by members of a closed community such as the military, and the resulting word or expression may eventually become part of everyday language, as evidenced by the metaphorical verb "cannibalize" (use spare parts from a machine, an aircraft, etc. to perform maintenance on equipment of the same kind).

Antoine's magnifying glass is very probably at work in a first group of metaphors in our dataset, which playfully refer to animals, as in a "bird" (a helicopter), a "bolter" (a missed attempt to perform an arrested landing on an aircraft carrier, necessitating a go-around a metaphor that is based on a horse that bolts, i.e. runs away very fast), a "jockey" (a fighter pilot), "squids" (used by members of other services to describe members of the U.S. Navy), the "barn" (a hangar for aircraft), or a "trench monkey" (a derogatory term for a member of the U.S. Army).

21 Humor appears to be the driving principle of metaphors belonging to U.S. military jargon, as in "fruit salad" (the medals and ribbons on a dress uniform), "scrambled eggs" (the golden embellishments found on some officers' caps), "hangar queen" (an aircraft that never leaves its hangar, due to constant maintenance problems), "Power Point Rangers" (officers who mainly participate in meetings at the headquarters instead of serving on the field), or "Ali Baba" (a term that started to be used during the first Gulf War to designate enemy forces).

We found that metaphorical allotopia was often quite significant in several highly inventive metaphors, as in "all velocity, no vector" (an individual proceeding at breakneck speed in no particular direction, a nickname for ambitious junior officers.), 
"Gone Elvis" (a service member missing in action), or "a Casper" (a service member akin to a ghost who always disappears when there is work to be done).

\subsection{Paronyms (semantic slips)}

Although a very minor matrix of military jargon in our dataset, paronyms are used at times by service members to create playful terms or expressions, as in "Army Crimes" or "Army Slimes," based on the name of U.S. Army's newspaper (the Army Times).

\subsection{Euphemization}

Not frequently employed in military jargon, euphemization may nevertheless help create neologisms such as "R\&R" ("Rest and Recreation" or "Rest and Recuperation"), which, as we know, designates off-duty time that often involves drinking heavily, or frequenting prostitutes.

\subsection{Simple composition}

Examples of simple composition were scarce in our dataset: "fuckstick" is an offensive term used by U.S. Marines Drill Instructors to address recruits at boot camp, the "goat locker," a U.S. navy term, is the mess where senior non-commissioned officers have their meals, and "speed bumps" is a tanker's derogatory term for infantry soldiers.

\section{Morphological matrices}

\subsection{Affixes}

We did not find any example of jargon created through prefixation or parasynthetic derivation ${ }^{22}$ in our dataset. Suffixation was used at times, but did not appear to be a highly productive matrix ${ }^{23}$ for military jargon. We found only two examples of items with suffixes: "fobbit" (military support personnel who never patrols outside a Forward Operating Base or F.O.B., i.e. a solitary outpost in hostile territory such as the Afghanistan mountainous areas), and "geardo" (a soldier who spends an unreasonable amount of money on personal military equipment). In fact, suffixation appears to intervene as a secondary process in the neology of U.S. military jargon: it may be used after a first lexicogenic matrix has produced a new term or expression, as in "zoomie" (a term for Air Force personnel, originally based on the metaphor of a fast-moving jet that "zooms" across the sky).

\subsection{Truncations}

\subsubsection{Simple truncations}

We observed several truncations in our dataset. A "Bilat" was used by U.S. forces in Iraq to refer to bilateral conferences between U.S. military officials and local Iraqi leaders, "Terps" is a truncation of "interpreters," "Camp Ass" designates Camp As Sayliyah, an Army base in Qatar, "The Lick" Incirlik Air Force base in Turkey, the "Cat" is a catapult on 
board U.S. Navy carriers, and "unsat" means anything that is not up to expected standards (i.e. "unsatisfactory").

\subsubsection{Truncations combined with suffixation} make up unofficial abbreviations to deride some unpleasant aspects of military life. Abbreviations were one of the most productive lexicogenic matrices in our dataset (28 items out of 190). Humor appears to be the principal function of these abbreviations: FIGMO for example, stands for "Fuck It, I Got My Orders," BOHICA for "Bend Over, Here It Comes Again"24," REMF for "Rear Echelon Mother Fucker," DEROS for "Day when I Evacuate this Region of Shit," while BOLO ("Be On the Look-Out") means "something bad," and "can be used as a noun when something goes wrong ("That's a bolo"), or a verb ("I bolo'd that task") 25 ." Official events can be debunked by derogatory abbreviations, as in WOMFT inspection ("Waste of my Fucking Time inspection"). The very names of armed services can also be turned into wry fictitious abbreviations, as in N.A.V.Y. ("Never Again Volunteer Yourself"), M.A.R.I.N.E. ("My Ass Rides in Navy Equipment"26), or M.A.R.I.N.E.S. ("Many Americans Running Into Never Ending Shit"). Some of these lexical items gradually lose their status as abbreviations and are routinely used as nouns (P.O.G., for instance, originally meant "People Other than Grunts," but is now used as a derogatory noun - "pogues," pronounced similarly to "rogue" - to designate non-combatant staff).

\subsection{Amalgamation and portmanteau words}

Another known, although perhaps less productive, matrix of jargon, is amalgamation. U.S. military jargon includes some "portmanteau words" resulting from a merger of two lexical items: already in use in the Vietnam war, "medevac" is both a noun and a verb referring to medical evacuations by helicopter. "Voluntold" is "an assignment that is technically voluntary but understood to be mandatory," 27 "mandofun" stands for "mandatory office dinner parties or get-togethers," 28 and "midrats" for "midnight rations." "Rumint" (coined after words ending with the suffix -int for "intelligence," such as "humint" - human intelligence), means "gossip" and merges the words "rumor" and "intelligence." A more sophisticated example is "Bombaconda," which stands for the "Logistics Support Area Anaconda," a major supply base near Balad, Iraq. In this specific item, we see two lexicogenic matrices at work simultaneously: a metonymy first "extracts" the concept of "bomb" from the nature of the military facility in Anaconda (which keeps aircraft well stocked in ammunition), then the word "bomb" is amalgamated with the location of the base. 


\subsection{Derivation}

31

Derivation can be a productive lexical matrix, as we can see in the case of scandals given a "-gate" suffix by the media (as in "Watergate"): "Monicagate", "FIFAgate", "Dieselgate", among countless examples. However, in our dataset, we found only one example of a possible derivation: "the Chair Force" (i.e. Air Force personnel not performing combat duties), but this particular expression could also be interpreted as a phonological parallel (see section 6.2.).

\subsection{Back formation}

formation appears to be seldom used in U.S. military jargon. The sole example in our corpus was "boot" (a soldier lacking in experience), derived from "boot camp".

\section{Phonological matrices}

\subsection{Onomatopoeias}

Phonological matrices may also be used to create jargon. A few onomatopoeias were identified in our corpus: "hoo-ah" is a kind of battle cry used in the U.S. Army to express enthusiasm or readiness, while "oohrah" is used by U.S. Marines, and "ooh-yah" by U.S. Navy SEALS for similar purposes.

\subsection{Onomatopoeias}

\subsubsection{Rhyme patterns}

Rhyme patterns can also be used to form military jargon: "dope on a rope" is the expression used by U.S. Army airborne units to describe air assault soldiers; "full battle rattle" refers to the full gear ${ }^{29}$ soldiers should wear while on the field; the " $1^{\text {st }}$ Civ-Div" is the imaginary "civilian division" that Marines join when going back to normal life; the "ant chant" is the cheer a U.S. Navy crew says together before leaving port; the "roach coach" is a snack truck that stops at a pier where a ship is berthed; "mike-mike" describe $20 \mathrm{~mm}$ caliber ammunition; "drop your cocks and grab your socks" is an order yelled by U.S. Navy petty officers in the sleeping quarters to wake up personnel under their authority.

\subsubsection{Phonological parallels}

Phonological parallels also constitute a lexical matrix of jargon: the D-FAC (pronounced dee-fuck) is a derogatory term for dining facilities at military bases, while the "Shithook" is the derogatory name given to the $\mathrm{CH}-47$ Chinook, a U.S. Army helicopter.

\section{Collocational violations}

Sablayrolles [2006:6] identified a new lexicogenic matrix, which he designated as a "combinatory innovation:" while certain words can only enter into a limited number of 
collocational associations (the adjective cochère, for example, can only be used in French as a modifier of porte ${ }^{30}$ ). As a consequence, any novel collocational combination in which the original expression does not totally disappear may prosper as a neologism, as in "serial blagueur, serial menteur, serial niqueur, serial noceur, serial vanneur" (Sablayrolles [2012: 2]), all derived from the original "serial killer" and yet perfectly understandable, based on a shared knowledge of the initial expression. An example of this kind of neologism in our corpus would be "Lost Lieutenant Finder" (as in "lost keys finder" or similar expressions), a term for a handheld GPS unit. Other examples include the "Armored carnival regiment" (a U.S. Army Armored Cavalry Regiment), "dirt diving" (a plane crash), or "black on ammo" (short on ammunition).

As this semantic matrix is based on an infringement of traditional collocational associations, we propose to term this kind of neologism "collocational violations." As can be seen in examples such as "bulkhead remover" (an imaginary detergent that seasoned U.S. Navy sailors often ask new sailors to find - "bulkhead" is a naval word for "wall"), humor again appears to be the main objective of this kind of slang.

\section{Semi-metaphorical fictitious idioms}

We also found, although not in significant numbers, expressions such as "a pig looking at a wristwatch" (a person with a dumbfounded look), or a "Come to Jesus speech" (a conversation in which an officer disciplines a subordinate), which do not fall under the categories already described above. Finding an appropriate label for these phrases is difficult, but we would tentatively describe them as "fictitious idioms" based on a phraselevel lexicogenic matrix, as they appear to match the traditional definition of idioms ("a group of words whose meaning cannot be predicted from the meanings of the constituent words, as for example (It was raining) cats and dogs" ${ }^{31}$ ), although, as opposed to most idioms, they do seem to carry a certain underlying metaphorical value (e.g. the "Come to Jesus Speech" is meant, by setting things straight, to bring about some degree of "epiphany" ${ }^{32}$ in the service member that is being disciplined). Further analysis on a larger corpus of similar phrases would allow to refine this preliminary categorization.

\section{Institutional roles of U.S. military jargon}

According to Burke [2013], military slang has a differentiating function (using a distinctive, arcane lexical register distinguishes service members from civilians), introduces humor to tedious occupations, allows to relieve anxiety and tension, and is also used to vent anger at the military hierarchy, with whom lower-ranking personnel may be frustrated. The roles of military jargon are therefore diverse: in this section, we attempt to delineate them. As opposed to the technolect, whose sole purpose consists in giving official military designations to concepts, actions or things, its primary function is not referential. After analyzing our dataset, we identified six different roles: bonding, humor, expressing negative stance, expressing stereotypes, encryption, and implicit narrative. 


\title{
8.1. Bonding
} removed.

\begin{abstract}
[...] the military is both a distinctive way of life and a community, and a command of what we might call the community's "folk speech" - its slang - is essential for admission to full membership within the group. Some military folk speech is familiar almost exclusively to the troops. A shit screen for example, is the fall guy, the person who takes the blame for some foul-up or infraction.
\end{abstract}

This suggests that military jargon has a gatekeeping function: being knowledgeable in a shared lexical code provides access to an insider's status within the military community.

Therefore, it seems that one of the essential functions of U.S. military jargon is building rapport and esprit de corps. This appears to be particularly true in the U.S. Navy, whose personnel is trained as of boot camp to use naval jargon, which contains several special or traditional words (some dating back to the age of the sail). The incorporating role of naval jargon is emphasized by Gillespie [2012:128], who describes terminology-based hazing pranks played on inexperienced sailors:

One way in which new sailors are made aware of their lowly status is through the use of slang in hazing rituals. Capitalizing on their ignorance of jargon, old hands send them on fool's errands designed simultaneously to humiliate, initiate, and educate them. For example, the newbie may be told to locate and bring back a "boatswain's punch." He presents himself at this warrant officer's cabin, makes his request, and is immediately punched very hard by the veteran sailor. Or a veteran may task a new sailor to find a can of "bulkhead remover," which he searches for in vain until being informed that, bulkheads being ship's walls, they are never

An official naval slang dictionary (a rather contradictory concept) published by the U.S. Navy in $1942^{33}$, indexes several words or expressions that are still in use in the service nowadays: "chow" (food), "scuttlebutt" (gossip), "greaseball” (mess cook), "sea lawyer" (a sailor who gives unwanted advice), or "tin can" (a destroyer), which tends to show that naval jargon is part of a shared heritage sanctioned by the Navy as an institution, because it contributes to building social cohesion, and ultimately, combat efficiency in the service.

In fact, jargon is given an almost official status in the U.S. Navy, as evidenced by The Bluejacket's Manual (Cutler [2015]), a basic handbook for all naval recruits ${ }^{34}$ :

Just as doctors, lawyers, baseball players, engineers, artists and police officers have their own language when communicating within their professions, the Navy too has its own special terminology. Doctors speak of contusions and hemostats, baseball players have their own meanings for "in the alley" or "ahead in the count," and police officers use special words like "perp" and "SWAT." In the Navy, special terms include helm, anchor, leeward, port, starboard, aft, bitts, chocks, and bollards for nautical equipment and concepts.

While the terms listed are "terms of art," associated with seamanship, the Bluejacket's Manual also suggests more informal vocabulary:

Everyday items also take on new names in the Navy, where bathrooms are heads, floors are decks, walls are bulkheads, stairways are ladders, and drinking fountains are scuttlebutts. You go topside instead of upstairs and below instead of downstairs. [...] [Cutler 2015: 10-11)

Further, the Manual highlights the fact that using special terms will allow sailors to assert their identity as members of the service: 
Many of these terms will seem strange to you at first, but you will get used to them and will soon be using them naturally. Remember that many of these terms come from a long history of seafaring and nautical traditions. By using them, you identify yourself as a member of a unique and very special group. [Cutler 2015: 11] and may expose service members to lethal dangers: creating and using amusing jargon can be a way of "letting off steam." Humor can clearly be seen in expressions such as "fart sack" (a sleeping bag), "LPCs" ("leather personnel carriers," i.e. boots), "nut to butt" (an order to tell soldiers to line up in a tight, forward facing line), "shake and bake" (a bombing attack based on a combination of conventional bombs, cluster bombs and napalm), "soup sandwich" (a situation that has gone wrong), "meat wagon" (an ambulance), "sniper check" (a salute given to an officer in the field), the " 4 dicks of death" (beef sausages with beans included in military survival rations), or the "1D-10T form" (a non-existent administrative form that ignorant service members, new to their unit, are sent to find). Popular culture can also be used to express funny expressions, as in "Obi Wans" (flashlights used on military airfields to direct vehicles in nighttime operations, which are identified as miniature "light sabers").

\subsection{Expressing negative stance}

U.S. military jargon often expresses a negative stance adopted by service members towards unpleasant aspects of military life. The "five-sided puzzle Palace" is a wellknown expression for the Pentagon (implicitly described as a useless bureaucracy), 
"comics" refers to maps presented by intelligence personnel, "rocks and shoals" designates U.S. Navy internal regulations, and "media pukes" is another name for reporters. Some expressions such as "fun in the sun" (boot camp), or "eat shit and bark at the moon" (a U.S. Navy SEALs expression meaning "eat your survival rations and hold your current position") playfully deride the constraints associated with operations on the field. Officers are often debunked in military jargon, as in "enswine" (a U.S. Navy ensign), or "Elvis and his entourage" (a general performing an inspection on a military site, followed by a gaggle of aides).

Negative stance is also present in expressions serving to debunk other services or other categories of military personnel: U.S. naval personnel thus refer to members of the Coast Guard as "knee-deep sailors" or "puddle pirates," and to their institution as "Uncle Sam's canoe club." Washington officials or experts who have never been in the field or see action are described as "Beltway clerks." In the U.S. Navy, an "Air Force Salute" is a shrug of the shoulders expressing ignorance.

\subsection{Expressing stereotypes}

A fourth role consists in expressing stereotypes about military life or the military environment. Military food is often identified with feces or poison, as in "SOS" ("shit on a shingle", or creamed chipped beef on toast), "death from within" (the alleged motto of U.S. Marine Corps cooks) or "baboon ass" (corned beef). Another frequent stereotype if that of military equipment identified as a useless, unreliable gadget, as in "Mattel-oMatic" (an M-16 submachine gun, whose stock is made of plastic, like toys manufactured by the Mattel corporation) or the "Nintendo Jet" (the A-F-18, a heavily computerized aircraft).

\subsection{Encryption}

One of the fundamental roles of jargon is encryption. Using expressions such as "check your six" (a military aviation code used to advise a wingman to check whether enemy aircraft are "at six-o-clock," i.e. flying in the rear and preparing to attack) may allow military personnel to encrypt simple messages such as "watch out behind you" or "check out the person behind you." Another known "coded" expression is "Embrace the Suck" (which means "the situation has gone bad, but let's deal with it"). A third example would be "zero dark thirty," ${ }^{37}$ which means "half past midnight," or, more generally "very early" at night. The secretive and arcane nature of jargon is not specific to the U.S. military: Calvet [1999: 4-5] indicates that the term "jargon" was used until the $17^{\text {th }}$ century in French to refer to "le langage des gueux," i.e. the language of bandits ${ }^{38}$, who needed to hide the meaning of their exchanges.

\subsection{Implicit narrative}

Finally, a limited number of terms or expressions in our dataset appeared to contain an implicit narrative. "Gum Shoe," for example, is U.S. Navy slang for a Cryptology Technician, and alludes to the first Cryptology Technician school on the roof of a building, where tar would get stuck to the bottom of students' shoes. This short narrative, only known to insiders, is metonymically packed into a lexical hint (the gum substance) 
embedded in the neologism. Similarly, "Great Mistakes" is the name (based on a rhyme pattern between "mistakes" and "lakes") naval personnel associate with the Great Lakes Naval Training Center, near Chicago, and alludes to the closure of two other U.S. training facilities in San Diego, California and Orlando, Florida, where weather conditions were far better.

\subsection{Role diagrams}

Some elements of military jargon may play several of the roles cited above. In this case, it is possible to build "role diagrams" by assigning a relative value to each of the 6 roles. If we select the term "baboon ass" (jargon for corned beef) for example, and assign a value from 1 (low) to 5 (very high) for each role, as in Figure 1 below, we obtain a "spider" diagram allowing to visualize the various functions of this particular expression. Of course, assessing a value for each role relies on a somewhat arbitrary appreciation on the part of the rater. For "baboon ass," for example, it is not unlikely that the primary institutional roles of this particular expression are "humor" and "expressing negative stance" (to which we therefore assigned the maximum value of 5), whereas no implicit narrative can be seen (justifying a nil value). Besides, this term does express the traditional military stereotype of food equated with poison (which appeared to justify a value of 4), while "bonding" and "encryption" did appear to be at work in this expression, probably justifying a value of 3 .

Figure 1: Estimated values of institutional roles for the term "baboon ass"

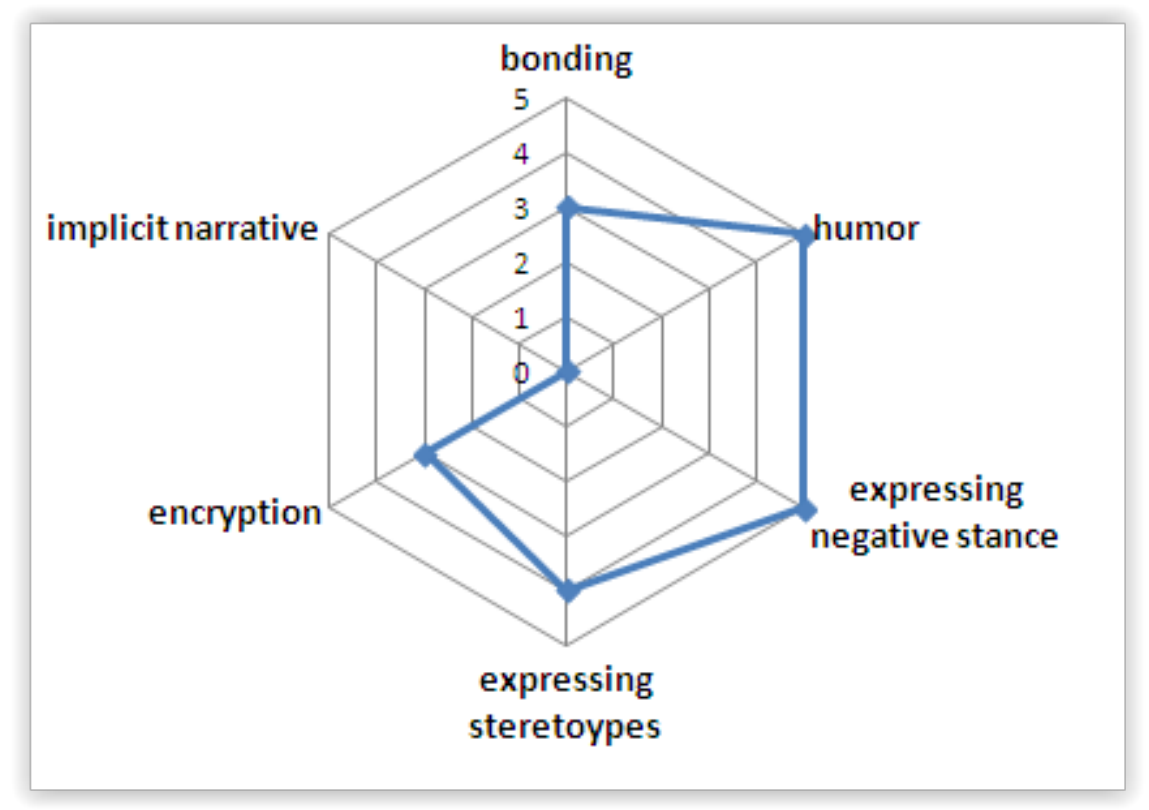

Building role diagrams may be helpful when indexing lists of jargon for lexicographic purposes, and, more generally, to ascertain in a more accurate fashion the specific functions played by each individual element of military jargon. 


\section{Conclusion}

Multiple lexical matrices are used by American service members to create jargon Metaphors and abbreviations provide a significant proportion of the terms and expressions in our dataset, but we did not identify any dominant type of matrix in U.S. military jargon. In this respect, the lexicogenic mechanisms in the military do not seem to differ from those used to create "civilian" slang. A special feature of U.S. military jargon, however, is its lack of synonymic dispersion, whereas, according to Calvet [1999: 45], synonymic profusion is one of the defining characteristics of slang: "creators of slang use a lexis that designates few things, but does so with a very large number of synonyms. ${ }^{39 "}$ French slang for "money" (flouze, artiche, caillasse, oseille, pognon, for example) is a striking example of synonymic profusion. We did not find any close synonyms evidencing synonymic profusion in our dataset, except for derogatory terms designating the Coast Guards ${ }^{40}$.

By conducting a bottom-up analysis of U.S. military jargon, and drawing on previous work by Tournier, Sablayrolles and Antoine, we were able to build a reprofiled taxonomy of lexicogenic matrices, including new categories such as "semanticization," "collocational violations," or "fictitious idioms." Given the inventiveness at work in military jargon, we cannot exclude that more categories may be needed to describe specific lexical items that we have not covered in this study: consequently, further research is probably needed on the taxonomy of lexicogenic matrices, as available models may not offer all the analytical tools needed by lexicographers to ascertain the genesis of jargon.

Another area for further research would be lexical code-switching: it has often been reported that American service members, while taking part in NATO or international operations, tend to mix the "official" technolect and tactical codes with U.S. military jargon when they communicate on radio tactical networks, which may bring about significant comprehension difficulties for non-American troops participating in an American-led coalition ${ }^{41}$.

61 Often satirical, transgressive, and offensive, U.S. military jargon conveys a tongue-incheek stance towards the constraints and the unpleasant aspects of military life. Its six key institutional roles (bonding, humor, expressing negative stance, expressing stereotypes, encryption, and implicit narrative), which all appear to take precedence over the referential role traditionally associated with any kind of slang, define its specialized nature and make jargon a key instrument of social cohesion within the U.S. military.

\section{BIBLIOGRAPHY}

ANTOINE Fabrice, 2004, « Argots et langue familière : quelle représentation en lexicographie bilingue? ", in ANTOINE Fabrice (ed.), Argots, langue familière et accents en traduction, Lille : Cahiers de la Maison de la Recherche, Ateliers 31, 11-23.

Lexis, 11 | 2018 
ANTOINE Fabrice, 2008, « De la thune à la caillasse : argent, argots et langue familière », in V ATANPOUR Sina (ed.), L'argent, Villeneuve d'Ascq : collection UL3, 329-339.

ANTOINE Fabrice, 2014, « Argots, métaphore et 'effet de loupe' », Lexis, n8, http:// lexis.revues.org/311

AXELROD Alan, 2013, Whiskey Tango Foxtrot: The Real Language of the Modern American Military, Amazon.com Kindle edition.

BAY Austin, 2007, Embrace the Suck: A Pocket Guide to Milspeak, New York: Pamphleteer Press. BONHOMME Marc, 1987, Linguistique de la métonymie, Bern : Peter Lang.

BURKE Carol, 2003, “Military speech”, New Directions in Folklore, No. 7.

CALVET Louis-Jean, 1999 [1994], L'Argot, Paris : PUF.

CLARK Gregory, 1990, Words of the Vietnam War: The Slang, Jargon, Abbreviations, Acronyms, Nomenclature, Nicknames, Pseudonyms, Slogans, Specs, Euphemisms, Double-Talk, Jefferson, NC: Mc Farland Publishing.

CHALOUPSKY Ladislav, 2005, A Sociolinguistic Interpretation of Military Slang and Vernacular Expressions , Ph.D. dissertation, University of Brno, Czech Republic.

CHARBONNEL Nanine, 1999, « Métaphore et philosophie moderne, » in CHARBONNEL, Nanine \& K LEIBER George (eds.), La métaphore : entre philosophie et rhétorique, Paris : Presses Universitaires de France, 32-61.

CUTLER Thomas Joshua, 2002 (centennial edition), The Bluejacket's Manual, Annapolis. MD: United States Naval Institute Press.

CORNELL George, 1981, “G.I. slang in Vietnam”, The Journal of American Culture, vol. 4, n² 2, 195-200.

DALzelL Tom, 2014, Vietnam War Slang: A Dictionary on Historical Principles, London: Routledge.

Department of Defense, DOD Dictionary of Military and Associated Terms, 2017, http://www.dtic.mil/ doctrine/dod_dictionary/

DICKSON Paul, 2014, War Slang: American Fighting Words \& Phrases Since the Civil War ( $3^{\text {rd }}$ ed.), Massachusetts, MA: Courier Corporation.

GILLESPIE Angus Kress, 2012, "Sea service slang. Informal language of the U.S. navy and coastguard", in ELIASON Eric A. \&TULEJA Tad (eds.), Warrior Ways: Explorations in Modern Military Folklore, Boulder, CO: University Press of Colorado, chapter 6, 116-138.

HOWARD Donald, 1956, “United States marine corps slang”, American Speech, vol. 31, n³, 188-194, http://www.jstor.org/stable/453678

LAKOFF George \& JoHnson Mark, 1980, Metaphors We Live by, Chicago, IL: The University of Chicago Press.

LE GUERN Michel, 1973, Sémantique de la métaphore et de la métonymie, Paris : Larousse Université.

LEVY Elinor, 2012, "Upper echelons and boots on the ground: The case for diglossia in the military", in ELIASON Eric A. \& TULEJA Tad (eds.), Warrior Ways: Explorations in Modern Military Folklore, Boulder: University Press of Colorado, chapter 5, 99-115.

MILLER Zell, 1998, Corps Values. Everything You Need to Know I Learned in the Marines, New York: Bantam Books. 
PAVEAU Marie-Anne, 1994, Le langage des militaires [The Language of Military Personnel], Ph.D. dissertation, Paris IV University.

REINBERG Linda, 1991, In the Field: The Language of the Vietnam War, New York: Facts on File.

RIORDAN John Lancaster, 1947, "Some notes on army slang”, American Speech, vol. 22, n³, 212-216, http://www.jstor.org/stable/3181800

ROMANOV A.S., 2014, "Military slang in the context of ethnic stereotyping", The Russian Journal of Linguistics, $\mathrm{n}^{\circ} 2,134-144$.

ROTTMAN Gordon, 2009, FUBAR, Soldier Slang of World War II, Oxford: Osprey Publishing.

SABER Anthony, 2006, Les milieux militaires américains et leurs discours [American Military Milieus and their Discourses]. Ph.D. dissertation, Bordeaux 2 University.

SABLAYROLLES Jean-François, 2006, « La néologie aujourd'hui », in GRUAZ Claude (ed.), À la recherche du mot : De la langue au discours, Limoges : Lambert-Lucas, 141-157, https://halshs.archivesouvertes.fr/halshs-00169475

SABLAYROLLES Jean-François, 2011, « Des néologismes par détournement ? Ou plaidoyer pour la reconnaissance du détournement parmi les matrices lexicogéniques ", in JULLION Marie-Christine, LONDEI Danielle \& PUCCINI Paola, Recherches, didactiques, politiques linguistiques : perspectives pour l'enseignement du français en Italie, Milan : Franco Angeli, 17-28, https://halshs.archivesouvertes.fr/halshs-00735933

TOURNIER Jean, 1985, Introduction descriptive à la lexicogénétique de l'anglais contemporain, ParisGenève : Champion-Slatkine.

WALLER Douglas, 2001, Big Red, The Three-Month Voyage of a Trident Nuclear Submarine, New York: Harpertorch.

\section{APPENDIXES}

\section{Appendix 1: Sources used to build the military jargon dataset}

\section{A/ Articles referring to military jargon written in the general press by former military personnel}

http://www.businessinsider.fr/us/phrases-only-people-in-the-military-know-2014-10/ http://www.latimes.com/news/la-op-bay28jan28-story.html

http://www.npr.org/sections/parallels/2013/12/04/248816232/u-s-military-lingo-thealmost-definitive-guide

\section{B/ Online glossaries curated by "military buffs"}

https://www.itstactical.com/intellicom/language/military-acronymsterminology-andslang-reference/

\section{c/ Websites dealing with "militaria"}

http://www.military.com/join-armed-forces/military-terms-and-jargon.html 
https://www.military1.com/army/article/403808-top-50-military-slang-words-andphrases/

http://www.itstactical.com/intellicom/language/military-acronymsterminology-andslang-reference/

\section{D/ An online U.S. Navy slang dictionary}

https://en.wiktionary.org/wiki/Appendix:Glossary_of_U.S._Navy_slang

\section{E/ Samples from a doctoral research dataset}

We also included in our dataset a selection of items from an original database of 281 items collected from 2003 to 2006 for previous doctoral research (Saber [2006]), which we had obtained from "G.I. Jargon.com", a now defunct website.

\section{Appendix 2: A table of lexicogenic matrices}

\begin{tabular}{|c|c|c|}
\hline \multirow[t]{2}{*}{ SEMANTIC MATRICES } & Semanticization & \\
\hline & Resemanticization & \\
\hline & Metonymies & \\
\hline & Metaphors & \\
\hline & Paronyms & \\
\hline & Euphemization & \\
\hline & Simple composition & \\
\hline MORPHOLOGICAL MATRICES & Affixation & Prefixation \\
\hline & & Suffixation \\
\hline & & Parasynthetic derivation \\
\hline & Truncations & Apheresis \\
\hline & & Apocope \\
\hline & Abbreviations & \\
\hline & Amalgamations & \\
\hline
\end{tabular}




\begin{tabular}{|l|l|l|}
\hline & Derivations & \\
\hline & $\begin{array}{l}\text { Back formation } \\
\text { (Inverse derivation) }\end{array}$ & \\
\hline PHONOLOGICAL MATRICES & Onomatopoeias & \\
\hline & Rhyme patterns or parallels & \\
\hline PHRASE-LEVEL MATRICES & Fictitious idioms & \\
\hline COLLOCATIONAL MATRICES & Collocational violations & \\
\hline EXTERNAL MATRIX & Loan words & \\
\hline
\end{tabular}

\section{Appendix 3: Remarks on the DoD Dictionary of military and associated terms}

This dictionary is curated and updated by the Department of Defense (DOD) Terminology Program, operating under the framework defined by Department of Defense Instruction 5025.12 (issued on August 14, 2009) on the "Standardization of Military and Associated Terminology," see http://www.dtic.mil/doctrine/dod_dictionary/ repository/502512_2017.pdf

The Instruction specifies that the role of the Terminology Program is "to improve communications and mutual understanding within the Department of Defense, with other Federal Agencies, and between the United States and its international partners through the standardization of military and associated terminology." The Instruction further specifies that "the DoD Components [should] use [the DoD Dictionary] as the primary terminology source when preparing correspondence, to include policy, strategy, doctrine, and planning documents," thereby conferring an "official" status to the lexis it contains.

New terms are included in the Dictionary if they meet four criteria, which are defined in Instruction 5025.12: "for a term to be considered for inclusion in [the DoD Dictionary], it must meet the following criteria:

a. Inadequate coverage in a standard, commonly accepted dictionary;

b. Terminology is of general military or associated significance. Technical or highly specialized terms may be included if they can be defined in easily understood language and if their inclusion is of general military or associated significance;

c. Term is not a code word, brevity word, or NATO-only term;

d. Term is not Component or Service-specific or functionality-specific unless it is commonly employed by U.S. joint forces as a whole." 


\section{NOTES}

1. Unplanned damage or casualties resulting from a bomb, missile or artillery strike.

2. A tactical procedure word meaning "I've understood your message."

3. Absent Without Official Leave (hence "to disappear" in everyday language).

4. "Fucked Up Beyond All Repair." As a testimony to the constant neological creativity of U.S. service members, FUBAR has been derived into new terms such as FUBIJAR ("fucked up but I'm just a reservist"), as indicated by Austin Bay, author of a military jargon glossary, https:// www.npr.org/templates/transcript/transcript.php?storyId=7458809

5. Even unseasoned military personnel may have difficulty grasping the meaning of military terminology, as evidenced by this passage from a narrative by Douglas Waller [2001: 49]: "Volonino [a junior naval officer] was sent to the USS Bluefish, a nuclear attack sub patrolling the Atlantic. He felt overwhelmed at first. All around him were junior officers only three or four years older than he, who were operating this complex machine and rattling off nautical terms in what sounded like a foreign language."

6. Further details about this dictionary are available from appendix 3.

7. Criteria for the inclusion of terms in the DoD Dictionary are available from appendix 3.

8. A comprehensive list of brevity codes in use in the U.S. military can be retrieved from a document entitled Multiservice brevity codes, issued by the Air, Land and Sea Application Center in February 2002, http://www.dtic.mil/dtic/tr/fulltext/u2/a404426.pdf

9. Definition retrieved From Multiservice brevity codes, I-18.

10. Examples of prowords routinely used in the U.S. military can be found in U.S. Army Field Manual FM 1-02, Operational Terms and Graphics, released in September 2004, available from various websites, including http://www1.udel.edu/armyrotc/current_cadets/cadet_resources/ manuals_regulations_files/FM\%201-02\%20-\%200perational\%20Terms\%20\&\%20Graphics.pdf

11. Definition retrieved from U.S. Army Field Manual 1-02, 3-25.

12. For further details on this weapon, see http://www.ausairpower.net/GBU-28.html

13. Calvet [1999: 77] noted that everyday conversation was the principal vector of jargon, and this had an influence on some of its lexical matrices in French. For example, apocopes or aphaereses are processes typical of oral interaction, as opposed to abbreviations, which pertain to a written register.

14. Examples include http://www.1stcavmedic.com/glossary.html and http:// www.atroop412cav.com/jargon_slang/, curated by members of Cavalry units.

15. We do not distinguish between jargon and "slang": given our definition of jargon already set forth above, both terms cover the same type of lexis, i.e. informal and unofficial.

16. Our translation. The original passage reads as follows: « Les menuisiers, les cultivateurs, les pêcheurs, etc., ont [...] un vocabulaire, tout simplement parce qu'ils ont besoin de désigner avec précision des objets ou des actions que les non-spécialistes ne distinguent pas ".

17. https://www.history.navy.mil/research/library/online-reading-room/title-listalphabetically/g/gedunk.html

18. This expression may be used on radio tactical networks.

19. This particular expression is used in the Marine Corps, while other letter groupings may be used across different services.

20. As evidenced, for example, in https://www.mca-marines.org/leatherneck/military-phoneticalphabet

21. This is due to the relatively free, irrational and spontaneous nature of lexicogenesis of metaphors in the field of jargon, as opposed to more "intellectual" mechanisms of metaphorical 
creation, which are based on successive comparisons between the two topic areas (this process is often termed "le parcours de sémème" by Francophone semanticians).

22. A lexicogenic mechanism also based on the simultaneous use of a prefix and a suffix, as in the French word "alunissage" (Moon landing, based on the French word "lune").

23. Although it can be combined with other matrices, notably truncation (see section 4.2.).

24. According to A. Bay [2007], this particular abbreviation was already in use in the U.S. Army in the 1960s.

25. Definition retrieved from http://itstactical.com

26. This refers to the fact that Marines are frequently posted on U.S. Navy amphibious warfare vessels prepositioned in a conflict area, ready to conduct an amphibious assault if needed.

27. Definition retrieved from http://military.com

28. Definition retrieved from http://businessinsider.fr

29. A flak jacket, body armor, ammunition, water, rifle and food rations.

30. A porte cochère is a carriage door.

31. https://www.collinsdictionary.com/dictionary/english/idiom

32. Understood as "a moment of sudden insight or understanding", https:// www.collinsdictionary.com/dictionary/english/epiphany

33. https://www.history.navy.mil/research/library/online-reading-room/title-listalphabetically/h/how-the-navy-talks.html

34. The first edition of this manual was published in 1902.

35. See definition above.

36. The antonym of this term is a "shellback."

37. An expression popularized by Kathryn Bigelow's movie about the hunt for Bin Laden.

38. "Gueux" also refers to paupers in French.

39. Our translation: "Les argotiers utilisent un vocabulaire qui nomme peu de choses, mais le fait avec de très nombreux synonymes."

40. Puddle pirates, knee-deep sailors and Uncle Sam's Canoe Club.

41. Admiral John Kirby, head of the U.S. Navy's communications, advised sailors to use less jargon and gibberish in a memo issued in 2013. See at http://www.lemonde.fr/ameriques/ article/2013/08/10/la-marine-americaine-en-croisade-contre-le-jargon_3459801_3222.html

\section{ABSTRACTS}

Specialized lexis used by American military personnel includes an official technolect, technical nomenclatures, tactical codes, as well as an abundant, diversified jargon. The latter is spontaneously created by the members of military units, and relies on several lexicogenic matrices, which we attempt to classify in this study by reformulating available descriptions of lexicogenic mechanisms. Metaphors and abbreviations account for a significant proportion of the 190 items in our dataset. An analysis of the institutional roles played by U.S. military jargon was also carried out: alongside bonding, humor and encryption, this lexical material also serves to recount implicit narratives, express negative stance about the military, and formulate stereotypes about the constraints of military life. Building "role diagrams" allows to visualize the balance between these six roles for an individual lexical item. 
Le lexique spécialisé des militaires américains comprend un technolecte officiel, des nomenclatures techniques, des codes tactiques, ainsi qu'un jargon riche et diversifié. Créé spontanément au sein des unités de combat, ce dernier procède de multiples matrices lexicogéniques, dont cette étude propose une nouvelle typologie. Métaphores et abréviations représentent une proportion importante au sein d'une liste de 190 items lexicaux emblématiques du jargon militaire américain ; ce dernier est doté de plusieurs rôles institutionnels : instrument de cohésion sociale, souvent porteur d'une charge humoristique, il peut aussi receler des récits implicites, porter des jugements négatifs sur l'institution militaire, ou des stéréotypes liés à la condition de soldat, mais aussi servir de code verbal et de signe de reconnaissance entre membres d'une même communauté militaire. L'élaboration de "diagrammes de rôles » permet de visualiser la part respective de ces six fonctions pour un même item lexical.

\section{INDEX}

Mots-clés: jargon, anglais militaire, anglais maritime, terminologie militaire, matrices lexicales, néologismes

Keywords: jargon, military English, maritime English, military terminology, lexical matrices, neologisms

\section{AUTHOR}

\section{ANTHONY SABER}

LACES (Laboratoire Cultures, Éducation, Société, EA 7437) / ESPri (English for Specific Purposes research initiative, ENS Paris Saclay)

anthony.saber@ens-paris-saclay.fr 